\title{
Transforming growth factor (TGF)- $\beta 1$ conjugated chitosan film for enhanced osteoblastic activity
}

\author{
Yoon Jeong Park2,4, Jue-Yeon Lee ${ }^{2,4}$, Kyung-Hwa Kim ${ }^{1,4}$, Tae-II Kim¹, Myung Hee Lee ${ }^{3,4}$, \\ Seung-Yoon Shin ${ }^{1,4}$, Yang-Jo Seol ${ }^{1,4}$, Yong Moo Lee ${ }^{1}$, In Chul Rhyu ${ }^{1}$, Young Ku ${ }^{1,4}$, \\ Soo Boo Han', Byung Moo Min ${ }^{2,3}$, Seung Jin Lee ${ }^{3,4}$, Chong-Pyoung Chung ${ }^{1,4 *}$ \\ 1Deprtment of Periodontology, College of Dentistry, DRI, Seoul National University, 28-2 Yongon-Dong, \\ Chongno-Ku, Seoul 110-749, South Korea \\ 2Department of Craniomaxillofacial Reconstructive Science, College of Dentistry, DRI, Seoul National \\ University, 28-2 Yongon-Dong, Chongno-Ku, Seoul 110-749, South Korea \\ ${ }^{3}$ Department of Industrial Pharmacy, College of Phamacy, Ewha Womans University, 11-1 Daehyun- \\ Dong, Seodaemun-Ku, Seoul 120-750, South Korea \\ ${ }^{4}$ Intellectual Biointerface Engineering Center (IBEC) at Seoul National University, Korea Science and \\ Engineering Foundation (KOSEF)
}

\section{Introduction}

Recent approaches of immobilization of bioactive molecules onto biomaterials have gained much interest in tissue engineering procedure as the surface molecule can modify/enhance cell and tissue responses. Covalent immobilization of bioactive peptide such as arginine-glycine-aspartic acid (RGD) peptides on material surfaces has shown to induce rapid colonization of endothelial and bone cells around implanted material surface. ${ }^{1-4)}$ While RGDpeptides primarily mediate adhesion of cells to substrates, immobilized growth factors may be able to modulate subsequent cell functions, such as prolifer- ation, differentiation, and activity on biomaterial surfaces. For example, epidermal growth factor (EGF) was coupled to a polystyrene plate induced phosphorylation of the EGF receptor. 5) In addition, the studies using titanium alloy treated with BMP-4 showed significant induction of osteoblastic activity in pluripotent $\mathrm{C} 3 \mathrm{H} 10 \mathrm{~T} 1 / 2$ cells $^{6}$ ).

The objective of this study was to immobilize growth factor onto the surface of biomaterials to enhance cell-biomaterial interaction, thereby inducing rapid cell differentiation. The chemical conjugation achieved by using crosslinker was considered to be more stable than the simple coating. In this study, transforming growth factor (TGF)- $\beta 1$ was

Corresponding author: Fax: +82-2-741-6082, E-mail: ccpperio@snu,ac, kr

This study was supported by the grant from Korea Science and Technology Foundation (KOSEF) through Intellectual Biointerface Engineering Center (IBEC) of Seoul National University. 
immobilized on the surface of chitosan film to improve osteoblastic cell adhesion and mineralization. The TGF- $\beta 1$ has been studied as a potential induction factor for bone regeneration. ${ }^{7,8)}$ TGF- $\beta 1$, a member of the TGF- $\beta$ superfamily, is a disulfidelinked homodimer consisting of two 112 amino acid residue polypeptides and it has a molecular weight of approximately 25,000 . It is a multifunctional protein that regulates many aspects of cellular activity, including cell proliferation, differentiation, and extracellular matrix metabolism, in a time-and concentration-dependent manner.

Chitosan has been utilized for engineering tissues including cartilage, skin, bone and liver ${ }^{9,10)}$. Several attractive properties of chitosan, including minimal foreign body reaction, mild processing conditions, structural similarity to glycosaminoglycans, and presence of free amino groups for conjugation to proteins, render it widely used in the biomedical application. Growth factor has been loaded into porous chitosan scaffold as a soluble form in previous study ${ }^{11)}$. The release pattern of growth factor from the scaffold showed initial burst release over $45 \%$ of loading amount ${ }^{11)}$. However, direct coupling of TGF- $\beta 1$ on the surface of chitosan may eliminate the initial burst effect and the maintain TGF- $\beta 1$ for long term period. The immobilization technique could require small amount of TGF- $\beta 1$ compare to loading TGF- $\beta 1$ into scaffold. The immobilized TGF- $\beta 1$ can promote on the cellular behavior such as adhesion, proliferation, and differentiation.

In this report, the authors attempted to chemically immobilize rhTGF- $\beta 1$ onto the chitosan film and examined the interaction between osteoblastic cells and the surface by assaying osteoblastic cell attachment and differentiation capacity, which would be applied for effective guided bone regeneration (GBR) procedure.

\section{Materials and Methods}

\section{Materials}

Chitosan (m.w. 300,000, 98\% deacetylated) was purchased from Tae-Hoon Bio (Kyong-Book, Korea). Human recombinant TGF- $\beta 1$ was purchased form R\&D Systems (Minneapolis, MA, USA). Cross linker, which has maleimide functional group, was purchased from Pierce (Rockford, IL, USA). Collagenase, (-glycerol phosphate, L-ascorbic acid and glutaraldehyde were obtained from SigmaAldrich (St. Louis, MO, USA). Trypsin-EDTA, fetal bovine serum (FBS), (-minimum essential medium (MEM) were purchased from Gibco (Grand island, NY, USA). All solvents used were of analytical grade.

\section{TGF- $\beta 1$ immobilization on chitosan film}

Chitosan films were created by casting $2 \%(\mathrm{w} / \mathrm{v})$ solution of chitosan in $2 \%$ acetic acid into polystyrene multiwell plates ( $500 \mu \mathrm{L} /$ well for 24 well, 80 $\mu \mathrm{L} /$ well for 96 well). Films were air-dried for 2 days, then neutralized with $0.1 \mathrm{M} \mathrm{NaOH}$ for $1 \mathrm{~h}$, then washed with DDW until pH was neutral. Chitosan films were immersed in $0.1 \mathrm{M}$ phosphate buffer (PBS, pH 7.4) for $30 \mathrm{~min}$ and incubated in $5 \mathrm{mg} / \mathrm{mL}$ of cross linker solution prepared in PBS with shaking gently for $2 \mathrm{~h}$ in dark place. The optimum concentration of crosslinker was $20 \mathrm{mM}$ which was determined by previous study. Then washed with PBS to remove unreacted crosslinker, $100 \mathrm{ng} / \mathrm{mL}$ of TGF- $\beta 1$ in phosphate buffer ( $\mathrm{pH} 8.4$ ) was added to chitosan and incubated at $4{ }^{\circ} \mathrm{C}$ for overnight. The resultant chitosan substrates washed with PBS to remove unreacted TGF- $\beta$ 1. For comparison, chitosan film were soaked with $100 \mathrm{ng} / \mathrm{mL}$ of TGF- $\beta 1$ in phosphate buffer ( $\mathrm{pH} 8.4$ ) for overnight. Samples 
were washed with PBS three times to remove weakly bound protein.

\section{Characterization of surfaces}

Characterization of the TGF- $\beta 1$ immobilized chitosan surfaces is typically performed using X-ray photoelectron spectroscopy. XPS analysis was performed using a Perkin Elmer 5600 ESCA system. Setting the hydrocarbon peak maximum in the C1s spectra to $285.0 \mathrm{eV}$ referenced the binding energy scales for the samples. Survey scans and elemental scans were performed using a flood gun (charge neutralizer) setting of $5 \mathrm{eV}$ and nickel wire mesh held over the sample to prevent charging of the sample surface. Elemental scans of the TGF- $\beta 1$ immobilized chitosan were taken to detect for nitrogen (402 $\mathrm{eV})$, oxygen $(532 \mathrm{eV})$, and sulfur $(170 \mathrm{eV})$ on the surface. After the immobilization was finished, the supernatants were collected. The concentration of human recombinant TGF- $\beta 1$ remaining in the supernatant was measured by ELISA kit (R\&D Systems, Minneapolis, MA, USA) for TGF- $\beta 1$. The stability of immobilization between TGF- $\beta 1$ and chitosan was investigated under the condition described below. TGF- $\beta 1$ immobilized chitosan film (ca. $20 \mathrm{mg}$ by weight) were placed into $\mathrm{pH} 7.4$ phosphate buffer as releasing medium $(1 \mathrm{~mL})$. The sealed vials were placed in a water bath at $37^{\circ} \mathrm{C}$ and shaken at $15 \mathrm{rpm}$. At predetermined time intervals, samples were withdrawn from the vial and replenished with fresh medium. The concentration of released TGF- $\beta 1$ in the samples was assayed using ELISA kit (R\&D Systems, Minneapolis, MA, USA) for TGF- $\beta 1$.

\section{Cell attachment onto rhTGF- $\beta 1$ immo- bilized chitosan film}

The cell attachment activity of chitosan films with various amounts of rhTGF- $\beta 1$ was assayed in $24-$ well plates. The MC3T3 cells, detached with $0.02 \%$ trypsin-EDTA solution and resuspended in DMEM containing $0.1 \%$ BSA, were added (100 $\mu$, $\left.1 \times 10^{6} \mathrm{cells} / \mathrm{ml}\right)$ to each well and incubated at $37^{\circ} \mathrm{C}$ for $2 \mathrm{hr}$ in $5 \% \mathrm{CO}_{2}$. After unattached cells were washed off, attached cells were stained with a $0.2 \%$ crystal violet aqueous solution in 20\% methanol for $10 \mathrm{~min}$. The number of cells in three central fields of triplicate wells was counted and averaged. In addition, the morphology of the cells adhering to the membranes was observed by a scanning electron microscope. The cells were fixed with $2.5 \%(\mathrm{v} / \mathrm{v})$ glutaraldehyde in $0.1 \mathrm{M}$ phosphate buffered saline (PBS, pH7.4) in situ for 30min and then rinsed with $0.1 \mathrm{M}$ PBS. The cells were stained with $1 \mathrm{ml}$ of $1 \%$ $(\mathrm{v} / \mathrm{v})$ osmium tetroxide $\left(0^{\circ} \mathrm{C}\right)$ and placed on ice for 30 to $40 \mathrm{~min}$. The cells were then rinsed with distilled-deionized water and stored in a deep freezer ($70^{\circ} \mathrm{C}$ ). Prior to the scanning electron microscope observation, the fixed and stained cells were freezedried and sputter-coated with gold and palladium.

\section{Mineralization and alkaline phosphatase activity of hTGF- $\beta 1$ immobilized sur- face of the chitosan film}

The amount of calcium deposits in the osteoblasts cultured onto rhTGF- $\beta 1$ immobilized films for up to 4 weeks was measured by extracting calcium with $0.5 \mathrm{~mL} 5 \%$ trechloroacetic acid. Calcium content was determined by a colorimetric assay using ocresolphthalein comlexone (Sigma, St.Louis, MO). The calcium complex was measured spectrophotometrically at $575 \mathrm{~nm}$. A separate set of cells grown on the rhTGF- $\beta 1$ immobilized membrane were harvested and lysed in $0.2 \%(\mathrm{w} / \mathrm{v})$ Triton X-100 and $5 \mathrm{~mm} \mathrm{MgCl}_{2}$ and alkaline phosphatase activity was measured using a biochemical assay from Sigma. 
The assay was based on the conversion of $\rho$-nitrophenyl phosphatate to $\rho$-nitrophenol, which was measured colorimetrically at $405 \mathrm{~nm}$. Enzymatic activity was expressed in units, which were defined as nmoles of substrate digested $/ \mathrm{min}$. The volume that was left was used for total protein content determination.

\section{Statistical analysis}

All measurements were collected in triplicate and expressed as averages \pm standard error. Analysis of variance (ANOVA) was performed to compare the result from TGF- $\beta$ 1-2 - conjugated membrane and control groups. The $p$ value $<0.05$ was considered statistically significant.

\section{Results}

\section{TGF- $\beta 1$ immobilization}

Figure 1 shows the ESCA survey scan spectra of chitosan and TGF- $\beta 1$ immobilized chitosan surfaces. Chitosan showed three peaks corresponding

(A)



(B)

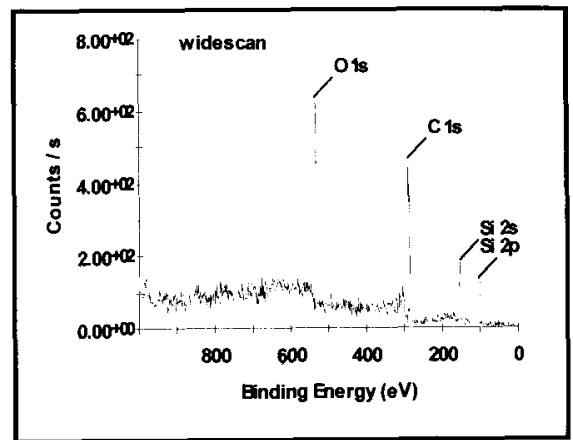

Figure 1. XPS analysis of (A) chitosan and (B) TGF- $\beta 1$ immobilized chitosan film.

Table 1. The XPS data of element contents on the surface of chitosan and TGF- $\beta 1$ immobilized chitosan film.

\begin{tabular}{lcccccc}
\hline Element & $\mathrm{O}(\%)$ & $\mathrm{N}(\%)$ & $\mathrm{C}(\%)$ & $\mathrm{S}(\%)$ & $\mathrm{O} / \mathrm{C}$ & $\mathrm{N} / \mathrm{C}$ \\
\hline Chitosan with no TGF- $\beta 1$ & 31.83 & 6.18 & 61.99 & 0 & 0.513 & 0.0997 \\
TGF- $\beta$ 1 immobilized chitosan & 36.33 & 1.96 & 60.05 & 4.66 & 0.605 & 0.033 \\
\hline
\end{tabular}


A

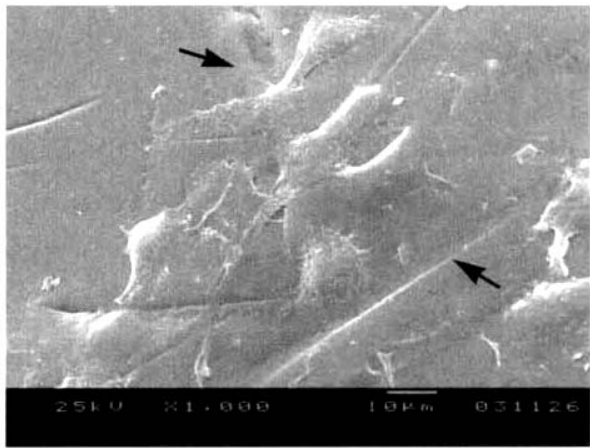

B

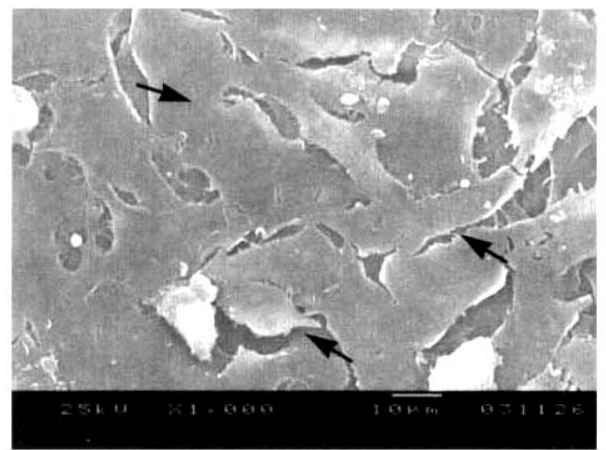

Figure 2. Scanning electron microscopy of attached osteoblasts to (A) non-immobilized chitosan and (B) TGF- $\beta 1$ immobilized chitosan film surface after $4 \mathrm{~h}$ incubation. Arrows indicate attached osteoblasts.

to C1s (binding energy $286 \mathrm{eV}$ ), O1s (binding energy $532 \mathrm{eV}$ ) and N1s (binding energy $399 \mathrm{eV}$ ), whereas TGF- $\beta 1$ immobilized chitosan showed an additional peak contributing S2p $(170 \mathrm{eV})$ and $\mathrm{N} 1 \mathrm{~s}$ peak was decreased. The chemical compositions of TGF- $\beta 1$ immobilized chitosan and chitosan without modification, calculated from the ESCA survey scan spectra, are shown in Table 1. The peak for sulfur was obtained and the ratio of $\mathrm{N} / \mathrm{C}$ was decreased on TGF- $\beta 1$ immobilized chitosan. This result demonstrated that TGF- $\beta 1$ was immobilized on the amine groups of chitosan via crosslinker.

\section{Cell attachment assay}

The morphology and extent of spreading were examined using a scanning electron microscopy. After $4 \mathrm{~h}$ culture period, a small degree of cell extending was observed on non-immobilized chitosan (Figure $2(\mathrm{~A})$ ). The shape of cells was spherical and aggregated while the number of attached cells was small. In contrast, cells on TGF- $\beta 1$ immobilized chitosan were well spread and formed a layer around the surface of chitosan film (Figure 2 (B)). The TGF- $\beta 1$ conjugated chitosan film showed

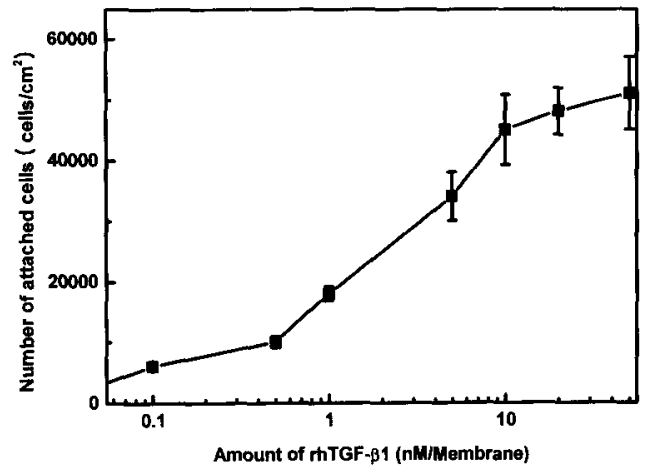

Figure 3. Attachment of osteoblasts to either TGF- $\beta 1$ conjugated or non-conjugate chitosan membranes. Cells were allowed to attach to either TGF- $\beta 1$ conjugated or control membrane for $4 \mathrm{hr}$, stained with crystal violet and counted as described in Materials and Method section. The data are represented as average \pm standard error. 
dose-dependent cell attachment activity (Figure 3). The number of attached cells increased in accordance with the amount of the conjugated TGF- $\beta 1$, however, it did not significantly increase further at a TGF- $\beta 1$ amount above $20 \mathrm{nM} / \mathrm{cm}^{2}$, showing saturation level of cell attachment. These results indicate that TGF- $\beta 1$ quantitatively reacted with the chitosan film and were active for cell adhesion.

\section{Alkaline phosphatase activity and min- eralization assay}

The osteoblast cells grown on the TGF- $\beta 1$ immobilized membrane was assayed their ALPase activity (Figure 4) and mineralization capacity (Figure 5) for up to 4 weeks. Cells on the TGF- $\beta 1$ immobilized film showed significantly higher ALPase activity at all time points, whereas membrane without modification induced limited activity from the surface. Calcium deposition for conjugated TGF- $\beta 1$ was higher than adsorbed TGF- $\beta 1$ surface, and surface with no TGF- $\beta 1$ for 4 weeks.

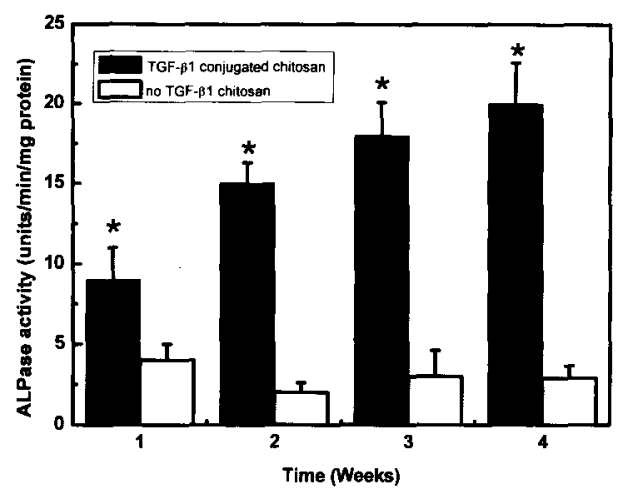

Figure 4. Alkaline phosphatase activity of osteoblasts cultured either on TGF- $\beta$ 1 conjugated or control chitosan membrane with no modification. Membrane without modification (no TGF- $\beta 1$ ) was served as a control. Data are represented as the average \pm standard error. *: statistically significant compared to that cultured on controi membrane $(p<0.05)$

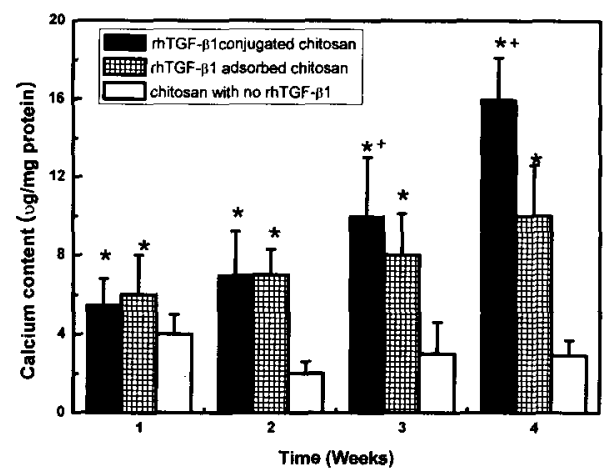

Figure 5. Calcium deposition of osteoblasts cultured either on TGF- $\beta$ 1conjugated or adsorbed chitosan membrane. Membrane without modification (no TGF- $\beta 1$ ) was served as a control. Data are represented as the average \pm standard error. *: statistically significant compared to that cultured on control membrane ( $p<0.05),+$ : statistically significant compared with that cultured on TGF- $\beta 1$ adsorbed membrane $(p<0.05)$ film. 


\section{Discussion}

Immobilization of biomolecules on the biomaterial surfaces enables localization and retention of these molecules at the cell-biomaterial interface. The immobilization of TGF- $\beta 1$ by using cross linker is more effective than the loading of growth factor by soaking method. Covalent bond formed between chitosan and TGF- $\beta 1$ is stable and surface immobilized TGF- $\beta 1$ can affect the osteoblastic cells function for whole culture period. The amine group existed on the surface of chitosan can be reacted with the crosslinker produce maleimide-functional surfaces. XPS analysis demonstrated that TGF- $\beta 1$ was immobilized on chitosan surface tightly and formed stable bond.

The morphology and extent of spreading were examined using SEM and confocal microscopy. Following $4 \mathrm{~h}$ of incubation, high cell density on TGF- $\beta 1$ immobilized chitosan surface was observed compared with non-immobilized chitosan surface. The adherent osteoblasts were tightly bound to the surface and could not be removed by washing or shaking. After 1 day of incubation, the degree of spreading and the number of attached cells are higher on the TGF- $\beta 1$ immobilized chitosan film compared to non-immobilized chitosan film. Surface immobilized growth factor is effective that cells must interact with growth factors at supra threshold concentrations and for a sufficient duration for induction of the desired cellular behavior. Furthermore, many growth factors are produced and act locally, which makes systemic delivery impractical or undesirable. This study investigated whether growth factor immobilized on biomaterial surface would enhance osteoblastic cells attachment and growth. These results suggested that immobilization of TGF$\beta 1$ on chitosan was achieved successfully and bioactivity of TGF- $\beta 1$ was maintained.
TGF- $\beta 1$ immobilized chitosan film demonstrated higher cell viability than that of non-immobilized chitosan. This higher cellular activity might be related to affinity of TGF- $\beta 1$ to osteoblastic cells. This result coinside with the cell morphology data described above, in that conjugated TGF- $\beta 1$ to chitosan maintained bioactivity and effective to the growth of osteoblastic cells. It is anticipated that the rapid attachment at initial culture time can affect the following cell growth and differentiation. Cell adhesion is controlled by the presence of extracellular matrix (ECM) components, transmembrane adhesion molecules and cytokine such as growth factor, thereby deciding future regeneration efficacy ${ }^{12-15)}$. The osteoblast cells grown on the TGF- $\beta 1$ immobilized membrane was assayed their ALPase activity (Figure 4) and mineralization capacity (Figure 5) for up to 4 weeks. The calcium level is proportional to the amount of differentiated bone cells. Therefore, the most effective scaffolds should exhibit the highest levels for calcium assay. It has been determined that the recognition of the TGF- $\beta 1$ by cell TGF receptor provides signals for cell adhesion, migration, and differentiation. Our results demonstrated that TGF- $\beta 1$ immobilization on the chitosan surface improved osteoblastic cells differentiation and mineralization.

Although the membrane with adsorbed TGF- $\beta 1$ induced a higher mineralization than unmodified membranes, the amount was significantly lower than membrane with conjugated TGF- $\beta 1$. The experimental results in this study are coincident with other reports describing surface immobilization of bioactive protein onto biomedical devices ${ }^{15-19)}$. The growth factors and active enzymes have been chemically immobilized onto polymeric thin film or titanium alloy and been assured their activity primarily on the conjugated surface of these materials. Although there have been concerns regarding bioactivity change after chemical modification ${ }^{18-20)}$, increased 
ALPase activity, mineralization over the culture time provides convincing evidences that immobilized TGF- $\beta 1$ could present bioactive surface for long term implantation of this GBR membrane. This is the study demonstrating the fact that immobilization of whole growth factors onto the chitosan film for GBR purpose promotes the osteoblastic cell functions by stably providing bioactive environment at the surface of the membrane, and studies related to the in vivo therapeutic efficacy of this immobilized TGF- $\beta 1$ is now in progress in our laboratory.

\section{Conclusions}

The surface of chitosan was modified with TGF- $\beta$ 1 to enhance osteoblastic cells function and tissue repair. The TGF- $\beta 1$ immobilized chitosan film enhanced cell adhesion and spreading compared to non-immobilized chitosan. TGF- $\beta 1$ immobilized chitosan surfaces exhibited an increase cell attachment, alkaline phosphatase activity and calcium level in comparison with non-immobilized chitosan surface. Therefore, growth factor immobilization can be applied to other biomaterials for implant and tissue engineering scaffold to enhance biocompatibility and cell function.

\section{Acknowledgement}

This study was supported by the grant from Korea Science and Technology Foundation (KOSEF) through Intellectual Biointerface Engineering Center (IBEC) of Seoul National University.

\section{References}

1. Holland J, Hersh L, Bryhan M, Onyiriuka E, Ziegler L. Culture of human vascular endothelial cells on an RGD-containing synthetic peptide attached to a starch-coated polystyrene surface: comparison with fibronectin-coated tissue grade polystyrene. Biomaterials 1996; 17: 2147-2156.

2. Grzesik JJ, Pierschbacher MD, Amodeo MF, Malaney TI, Glass JR. Enhancement of cell interactions with collagen/glycosaminoglycan matrices by RGD derivation. Biomaterials 1997; 18: 1625-1632.

3. Okamoto K, Matsuura T, Hokosawa R, Agokawa Y. RGD peptides regulate the specific adhesion scheme of osteoblasts to hydroxyapatite by not to titanium. J. Dent. Res. 1998; 77: 481-487.

4. Mann BK, Tsai AT, Scott-Burden T, West JL. Modification of surfaces with cell adhesion peptides alters extracellular matrix deposition. Biomaterials 1999; 20: 2281-2286.

5. Ferris DM, Moodie GD, Dimond PM, Gioranni CWD, Ehrlich MG, Valentini RF RGD-coated titanium implants stimulate increases bone formation in vivo. Biomaterials 1999; 20: 2323-2331.

6. Ito Y, Chen G, Imanishi Y. Micropatterned immobilization of epidermal growth factor to regulate cell function. Bioconjug. Chem. 1998; 9: $277-282$.

7. Kuhl PR, Griffith-Cima LG.. Tethered epidermal growth factor as a paradigm for growth factorinduced stimulation from the solid phase. Nat. Med. 1996; 2: 1202-1207.

8. Liu SQ, Ito $Y$, Imanishi $Y$. Cell growth on immo bilized cell growth factor. I. Acceleration of the growth of fibroblast cells on insulin-immobilized polymer matrix in culture medium without serum. Biomaterials 1992; 13: 50-58.

9. Puleo DA, Kissling RA, Sheu MS. A technique to immobilize bioactive proteins, including bone morphogenetic protein-4 (BMP-4), on titanium alloy. Biomaterials 2002 ; 23: 2079-2087.

10. Noda $M$, Camilliere JJ. In vivo stimulation of bone formation by transforming growth factor $\beta$ 
Endocrinology 1989; 124: 2991-2994.

11. Park YJ, Lee YM, Park SN, Sheen SY, Chung CP, Lee SJ. Platelet derived growth factor releasing chitosan sponge for periodontal bone regeneration. Biomaterials 2000; 21: 153-159.

12. Nimni ME. Polypeptide growth factors: targeted delivery systems, Biomaterials 1997 ; 28: 5-24.

13. Suh JKF, Mattew HWT. Application of chitosanbased polysaccharide biomaterials in cartilage tissue engineering: A review. Biomaterials 2000; 21: 2589-2598.

14. Shahabeddin L, Berthod F, Damour O, Collombel C. Characterization of skin reconstructed on chitosan cross-linked collagen-glycosaminoglycan matrix. Skin. Pharmacol. 1990 ; 3: $107-114$.

15. Hock JM, Canalis E, Centrella M. Transforming growth factor- $\beta$ stimulates bone matrix apposition and bone cell replication in cultured fetal rat calvariae. Endocrinology 1990; 6: 1257-1265.

16. Elcin YM, Dixit V, Gitnick G.. Hepatocyte attachment on biodegradable modified chitosan membranes : In vitro evaluation for the development of liver organoids. Artif. Organs. 1998; 22:
837-846.

17. Hong L, Tabata $Y$, Miyamoto $S$, Yamamoto $M$, Yamada K, Hashimoto N, Ikada Y. Bone regeneration at rabbit skull defects treated with transforming growth factor $\beta 1$ incorporated in hydrogels with different biodegradabilities. J. Neurosurg. 2000; 92: 315-325.

18. Ueda $\mathrm{H}$, Hong $\mathrm{L}$, Yamamoto $\mathrm{M}$, Shigeno $\mathrm{K}$, Inoue $\mathrm{M}$, Toba $\mathrm{T}$, Yoshitani $\mathrm{M}$, Nakamura $\mathrm{T}$, Tabata Y, Shimizu Y. Use of collagen sponge incorporating transforming growth factor- $\beta 1$ to promote bone repair in skull defects in rabbits. Biomaterials 2002; 23: 1003-1010.

19. Karageorgiou V, Meinel L, Hofmann S, Malhotra A, Volloch V, Kaplan D. Bone morphogenetic protein-2 decorated silk fibroin fibers induce osteogenic differentiation of human bone marrow stromal cells. J. Biomed. Mater. Res. 2004; 71A: 528-537.

20. Wiemann $M$, Jennissen $H P$, Rumpf $H$, Winkler L, Chatzinikolaidou M, Schmitz I, Bingmann D. A reporter-cell assay for the detection of BMP-2 immobilized on porous and nonporous materials. J. Biomed. Mater.Res, 2002; 62: 119-127. 
-국문초록-

\title{
변형성장인자가 고정된 키토산 필름의 골아세포 활성에 미치는 영향
}

\author{
박윤정 ${ }^{2,4}$, 이주연 24, , 김경화1,4, 김태일 ${ }^{1}$, 이명희 ${ }^{3,4}$, 신승윤 ${ }^{2}$, 설양조 ${ }^{1}$, 이용무 ${ }^{1}$, \\ 류인철1, 구 영1,4, 한수부1 , 민병무 ${ }^{2,4}$, 이승진 3,4 , 정종평1,4, \\ 1서울대학교 치과대학 치주과학 교실 \\ 2서울대학교 치과대학 두개악안면 재전과학 전공 \\ 3이화여자대학교 약학대학 제약학과 \\ 4서울대학교 지능형 생체계면공학 연구센터
}

골아세포의 생물학적 기능을 중진시키기 위해 키토산의 표면개질에 대하여 연구하였다. 생체적합성 천연고 분자인 키토산은 1차 아미노기를 소유하고 있으므로 적정한 공유결합제를 사용하여 세포성장인자와 같은 생 리활성을 지닌 단백질을 키토산의 표면에 고정시킬 수 있다. 본 연구에서는 키토산을 필름형태로 제조하여 세 포성장인자 중 형질전환성장인자를 고정하고 골아세포의 부착, 성장 및 분화를 증가시키고자 하였다.

형태전환성장인자의 고정화 효율은 단순한 홉착방법에 비해 높았으며, 표면에 형성된 공유결합은 매우 안정 하였다. 골아세포를 배양하여 초기세포부착능에 대한 영향을 연구한 결과, 배양 후 4 시간, 1 일째, 형질전환성장 인자를 고정한 키토산 표면에서 고정하지 않은 키토산의 표면에 비해 더 많은 수의 골아세포가 부착되었고, 더 많이 신장된 부착형태를 보였다. 세포활성정도와 배양 후 4주일째의 칼슘축적량을 측정한 결과, 형질전환성장 인자를 고정한 키토산 표면에서 고정하지 않은 키토산의 표면에 배해 더 높았다. 위의 결과는 키토산 표면에 형태전환성장인자의 고정이 성공적으로 이루어졌으며, 또한 실제로 활성이 있는 것이 중명되었다. 위의 연구 결과에서 형질전환성장인자로 고정된 키토산은 골아세포의 초기 부착 및 분화를 촉진시켰음을 알 수 있었던 바 성장인자의 표면고정은 임플란트 및 조직공학용 지지체에도 적용하여 생체적합성과 세포기능을 증진시키 는데 이용할 수 있음을 알 수 있었다.

주요어: TGF- $\beta 1$, chitosan, osteoblast, surface immobilization 